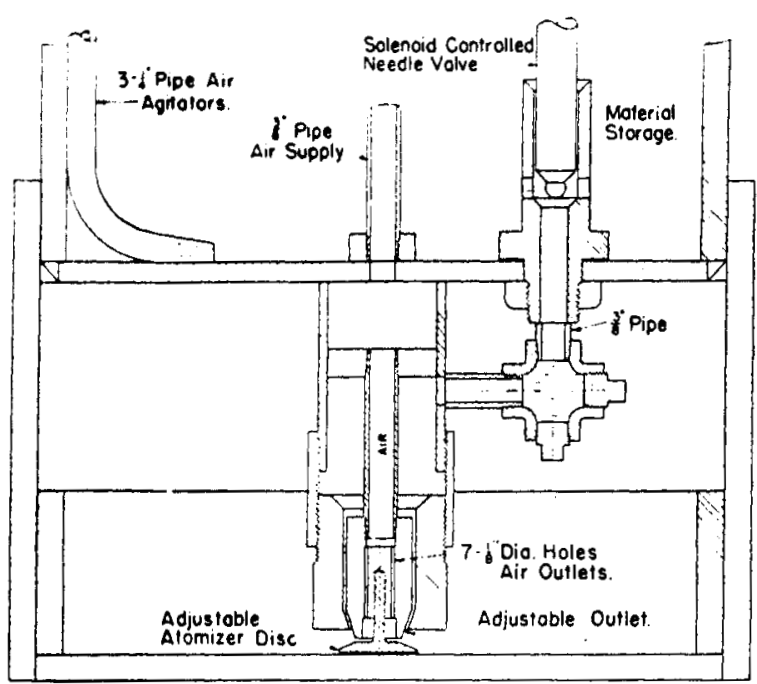

Fig. 3-A new type mold coating apparatus, developed to apply a thin uniform coating, uses a compressed air applicator.

The data in tables II and III show surface quality performance of Darmold vs. tar coated molds for billet and slab product. A comparison by grades of steel is shown in table II while in table III the data have been rearranged to show quality performance by type of product. The overall results of this comparison indicate a slight advantage for Darmold coated molds.

The case of semi-skilled steels under 0.30 pct carbon, the product from the Darmold coated molds definitely was superior to the product from tarred molds. In view of the critical nature of this grade with respect to surface quality, lower surface rejections from the product of Darmold

Table III

Comparative Cost, Mold Coatings

Material Cost Ratio

$\begin{array}{ll}\text { Virgin Tar } & 1.000 \\ \text { Graphite } & 1.250 \\ \text { Hydropaste } & 3.333 \\ \text { Darmold } & 5.000\end{array}$

coated molds were not expected, but nevertheless were gratifying.

Comparative mold coating costs, based on current market prices, are shown in table IV. Graphite has been included in the comparison because an extensive service trial with this material is scheduled in the near future. Preliminary experience with graphite has indicated that mold coating costs will not exceed appreciably that of tar. Quality performance data for graphite vs. tar coatings are not available.

Inasmuch as the present program for obtaining a satisfactory mold coating substitute for tar will not be completed for some time, quality performance and mold coating cost comparisons are not regarded as conclusive and may be subject to revisions at a later date. However, based on experience to date, it can be stated that with respect to quality and mold life, Darmold and Hydropaste appear to compare favorably with tar for coating molds. Unfortunately, mold coating costs with either are substantially greater than with tar. Darmold is readily adaptable to present equipment at Gary, while Hydropaste requires special mixing equipment and constant agitation

\section{Table IV}

Billet and Slab Product, Quality Performance, By Product

\begin{tabular}{llcc} 
Product & $\begin{array}{c}\text { Coating } \\
\text { Material }\end{array}$ & $\begin{array}{c}\text { Ingot } \\
\text { Tons }\end{array}$ & $\begin{array}{c}\text { Ratio of Sur- } \\
\text { face Rejec- } \\
\text { tions, Darmold } \\
\text { to Tar }\end{array}$ \\
\hline Slab & Darmold & 13466 & $0.950: 1$ \\
& Tar & 9978 & \\
Billet & Darmold & 23488 & $0.835: 1$ \\
& Tar & 11974 & \\
Total & Darmold & 36934 & $0.865: 1$ \\
& Tar & 21952 & \\
\hline
\end{tabular}

to maintain the desired consistency. Providing the contemplated experiments with graphite mold coatings show acceptable quality performance, this material will be attractive from a cost viewpoint. However, similar problems of mixing and agitation as encountered with Hydropaste are anticipated.

\title{
1949 Iron Ore Imports at Record High
}

$I^{2}$ MPORTS of foreign iron ore were greater in 1949 1 than in any previous year, with receipts totaling $8,300,000$ net tons from 18 countries, the American Iron and Steel Institute reports. This total represents an increase of 22 pct. over 1948, when imports totaled $6,800,000$ net tons. In 1947 about 5,492,000 tons were delivered, and in 1946 the imports totaled 3,085,000 tons. The largest supplies came from Sweden, Chile, and Canada.

Simultaneously, steel companies have been active in exploring and developing large ore deposits in South America, in exploring the Quebec-Labrador iron range, and in constructing facilities for shipment of ore from Liberia. This extension of ore supply lines has been taken to supplement domestic ores, particularly while research proceeds toward the economical use of the taconite and low grade ores abounding in the Lake Superior region.

Estimates of the capital investment required in the taconite program place the cost at $\$ 15$ to $\$ 20$ per ton of annual capacity for producing taconite concentrates. Thus, at least $\$ 300,000,000$ must be invested to make $20,000,000$ tons of taconite concentrate yearly. If the steel industry were to replace the present Lake Superior natural ore supply with a taconite supply alone, it would be faced with a capital investment in iron ore facilities of upward of $\$ 1,250,000,000$ at today's costs. 